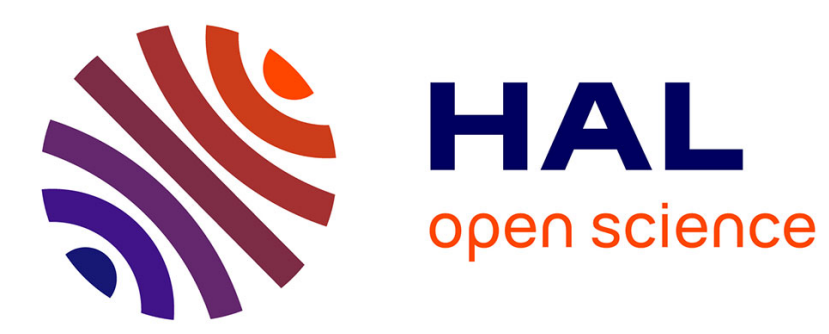

\title{
On commercial gluts Unexpected affinities between Jean-Baptiste Say and the Saint-Simonians
}

\author{
Adrien Lutz
}

\section{To cite this version:}

Adrien Lutz. On commercial gluts Unexpected affinities between Jean-Baptiste Say and the Saint-

Simonians. 2015. halshs-01199262

\section{HAL Id: halshs-01199262 \\ https://shs.hal.science/halshs-01199262}

Preprint submitted on 15 Sep 2015

HAL is a multi-disciplinary open access archive for the deposit and dissemination of scientific research documents, whether they are published or not. The documents may come from teaching and research institutions in France or abroad, or from public or private research centers.
L'archive ouverte pluridisciplinaire HAL, est destinée au dépôt et à la diffusion de documents scientifiques de niveau recherche, publiés ou non, émanant des établissements d'enseignement et de recherche français ou étrangers, des laboratoires publics ou privés. 


\title{
GATE

UMR 5824

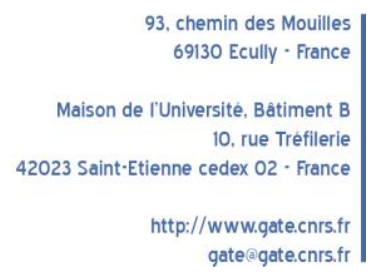

WP 1523 - September 2015

\section{On commercial gluts Unexpected affinities between Jean-Baptiste Say and the Saint-Simonians}

\section{Adrien Lutz}

\begin{abstract}
:
A standard reading in the history of economic thought considers Saint-Simonianism to be embodied in the works of a set of European social thinkers including Robert Owen, William Godwin and Sismondi, all of whom are seen as standing in strict opposition to the doctrine of laissez-faire. This article, however, argues that, during the first quarter of the 19th century, the Saint-Simonians and the liberal economist Jean-Baptiste Say can be seen to adopt convergent views on commercial gluts.

First, it shows how the Saint-Simonians and Say both see undersupply and lack of industry as causes of gluts. Next, we assert that their intellectual affinities are also visible in their belief that increasing production remains an appropriate solution for gluts. Finally, this convergence is explained by their common heritage: Saint- Simonianism is embedded in a neo-Smithian tradition for which Say can be taken as representative. We argue that this legacy explains their convergence.
\end{abstract}

\section{Keywords:}

Saint-Simonianism, Jean-Baptiste Say, Adam Smith, Laissez-faire, Commercial gluts

JEL codes:

B10, E5, N00

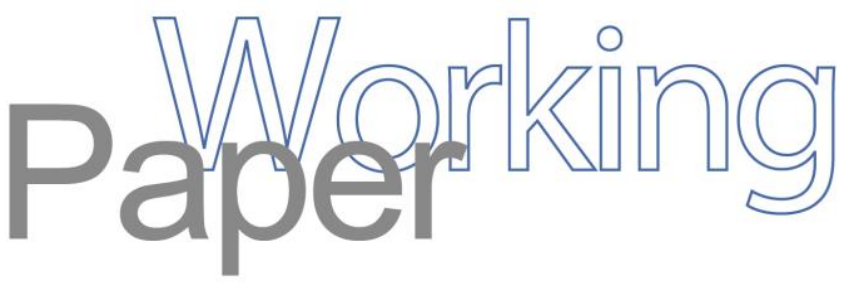




\title{
On commercial gluts \\ Unexpected affinities between Jean-Baptiste Say and the Saint- Simonians
}

\begin{abstract}
A standard reading in the history of economic thought considers Saint-Simonianism to be embodied in the works of a set of European social thinkers including Robert Owen, William Godwin and Sismondi, all of whom are seen as standing in strict opposition to the doctrine of laissez-faire. This article, however, argues that, during the first quarter of the 19th century, the Saint-Simonians and the liberal economist Jean-Baptiste Say can be seen to adopt convergent views on commercial gluts.

First, it shows how the Saint-Simonians and Say both see undersupply and lack of industry as causes of gluts. Next, we assert that their intellectual affinities are also visible in their belief that increasing production remains an appropriate solution for gluts. Finally, this convergence is explained by their common heritage: SaintSimonianism is embedded in a neo-Smithian tradition for which Say can be taken as representative. We argue that this legacy explains their convergence.
\end{abstract}

JEL Code: B10, E5, N00

Keywords: Saint-Simonianism, Jean-Baptiste Say, Adam Smith, Laissez-faire, Commercial gluts

\footnotetext{
${ }^{1}$ Université de Lyon, Lyon, F-69007, France ; CNRS, GATE Lyon Saint-Etienne, Ecully, F-69130, France ; Université Jean Monnet, Saint-Etienne, F-42000, France
} 


\section{Introduction}

Saint-Simonianism as a French intellectual movement was particularly influential in the period 1825-1832. But although such famous economists as Piero Sraffa (1929) and Friedrich Hayek ([1941] 1964) read and studied the Saint-Simonians, the movement became marginalized after 1945 with the growing influence of Marxist analysis in the history of socialist thought. This shift in influence reveals a fundamental division within the intellectual roots of socialism: Saint-Simonianism was seen as forming part of utopian Socialism, in opposition to the "true" Socialism - the intellectual one - proclaimed by Karl Marx and Friedrich Engels in their Manifesto ([1848] 1952). Recognizing this division, moreover, might lead us to consider SaintSimonianism as a mere pre-Socialism, characterized fundamentally by its opposition to the Classical political economy of Adam Smith, Jean-Baptiste Say and David Ricardo. Hence the Saint-Simonians have come to be confined to a black box of social reformists, set in opposition to the Classical economists. Indeed, Joseph Schumpeter sees Saint-Simonianism as a pre-Marxist Socialism (Schumpeter [1954] 2006, pp. 435-438) and Mark Blaug reads Henri Saint-Simon and Charles Fourier through the narrow prism of the Principles of John Stuart Mill (Blaug [1962] 1996, p. 184). Karl Pribram goes one step further: for him, Saint-Simonianism was part of French Socialism along with Sismondi and Fourier, and they were all unable to understand the mechanisms of an economic system (Pribram [1983] 1986, pp. 198-202). This literature thus sets the Classical stream in opposition to an inchoate group of reformists such as William Godwin, Robert Owen, Charles Fourier, Jean-Charles Léonard Sismondi, Louis Blanc and the Saint-Simonians. Here, however, we argue that there are several examples of intellectual affinities between these so-called opposite strands: hence, while Sismondi was happy to affirm that "the principles of Adam Smith served as [his] guides at all times" ([1827] 1991, p. 3), the SaintSimonians also based their views on the Smithian framework: the labor theory of value, the benefits of the division of tasks, and wealth as an object of inquiry. More precisely, we aim to show that this standard reading prevents us from successfully grasping the influence of Smith on these social reformists.

Hence, setting the classical framework inherited from Adam Smith in opposition to this set of social thinkers prevents us from clearly understanding these social reformers. In stark contrast with the standard reading, we argue that the frontiers between the Classical economists and the Saint-Simonians are simply not as clear as is commonly assumed in the history of economic thought: the controversy over commercial gluts - the excess of supply (encombrement) - which set Jean-Baptiste Say, David Ricardo, Robert Torrens and John Ramsay McCulloch against Sismondi and Robert Malthus (1819-1827), sees the Saint-Simonians sharing the views of the supporters of laissez-faire, especially Jean-Baptiste Say. This goes against the standard reading. The aim here is to shed light on this apparent paradox. As a result, we will be in a position to state that the relations between these groups are more complex than normally assumed: Jean-Baptiste Say (in Treatise of Political Economy, [1803] 2006, especially the fourth edition of 1819) and the Saint-Simonians (in Le Producteur, 1825-1826) both argue that overproduction is a phenomenon of undersupply, with two major causes (lack of mobility and industry) and one clear solution (increasing production). Resolving the paradox calls for inquiry into the doctrines' points of convergence, notably their concept of industry, which remains important to avoid gluts. In this respect, we will have cause to observe that these two apparently opposed strands of political economy both evolved in the same framework - that provided by Adam Smith. 
In the second section, we present Saint-Simonianism both as a physiologist philosophy and as an economic doctrine. From the former perspective, the SaintSimonians view society as a living body wherein every producer has a particular task to perform. Based upon this picture, the Saint-Simonian philosophy aims to generate greater industry within the productive system. This emphasis on industry remains a common theme in Jean-Baptiste Say's Treatise. In the third section, we argue that Saint-Simonianism provides an analysis of gluts which is particularly close to that developed in Jean-Baptiste Say's writings. The major cause of gluts in both doctrines concerns the repartition of capital and goods. More precisely, the system of production becomes characterized by a lack of industry: when commodities are not well distributed in the appropriate areas, industrialists miscalculate the required amounts of production. The fourth section reveals points of convergence regarding the solutions the Saint-Simonians and Say propose to avoid these gluts. More precisely we show that, in a non-monetary system, they both consider it necessary to increase production and its fluidity in order to avoid gluts. Hence they share the same view on the solution to this form of commercial crisis. In the last section we argue that Say and the SaintSimonians both lay emphasis on the neo-Smithian doctrines then current in France. Indeed, we argue that the study of the points of convergence between their two positions can provide new material for understanding Smith's legacy in France, which can be applied precisely in order to resolve our apparent paradox. With respect to their views on value, money and industry, the Saint-Simonians can legitimately be considered as heirs to a neo-Smithian doctrine.

\section{Economic strands of Saint-Simonianism: from physiology to industry}

In the field of political economy, Saint-Simonianism remains a largely forgotten doctrine. Nevertheless, the Saint-Simonians can be seen to offer an interesting view of society, drawing on physiology, in which it is seen as a living body wherein industrialists, artists and scientists live in an association framed by the needs of the whole. This physiologist strand paves the way to considering economic questions based upon the idea of the fluidity of production (in modern terms, factor mobility) and faith in industry. These Saint-Simonian concepts are explained in their journal Le Producteur, as is their position on the controversy over gluts, which also involves Jean-Baptiste Say.

\section{Saint-Simonianism as a physiologist philosophy}

The Saint-Simonian doctrine is complex and embodied in a massive body of work including three journals (Le Producteur, Le Globe, L'Organisateur) and a compendious exposition of the doctrine (see the translation by Georges Iggers 1972). It has generally been sociologists who have been interested in Saint-Simonianism: the famous sociologists who are known to have read and appreciated Saint-Simon's writings include Emile Durkheim (as noted in the preface to his Le socialisme (1928), by Pierre Birnbaum and Marcel Mauss), Pierre Ansart (1969, 1970), Célestin Bouglé (1925) and Georges Gurvitch (1955). In their view, the work of Saint-Simon (1760$1825)$ is the basis of sociology. Beyond sociology, the Saint-Simonian doctrine is also a philosophy which is embodied in a historical framework. The Saint-Simonians base their views on progress in medicine, especially in physiology, seen as the science which observes the external manifestations of organic life (as opposed to psychology, 
which studies inner experiences). For the Saint-Simonians, physiology begins as a science of the individual; but, through industry, this science becomes collective.

Industry specifies procedures which favor the preservation of life, and explores ways in which modifications of man's external nature can be of benefit to all members of society (Philippe Buchez 1826). In other words, physiology deals with the preservation of society, as it secures, through observation, the necessary elements for life in an industrialist society. History is a tapestry of improvements within which industry appears as the most important strand. Complemented by science and the fine arts, industry provides happiness, defined as an intellectual and material pleasure (Joseph Allier 1826). More precisely, happiness occurs where all individuals freely express their own abilities and succeed in being remunerated according to their work. Hence this concept is not only materialistic but also moralistic, as it is based upon two famous maxims: "from each according to his ability" and "to each ability according to its works" (à chacun selon ses capacités, à chaque capacité selon ses oeuvres). The concept of ability refers to knowledge and skills, as in the concept of human capital developed by Theodore Schultz (1961), but ability remains embodied in an imperative to produce. This highlights the fact that the Saint-Simonian project embraces economic, philosophical, moral and political considerations.

On this basis, the Saint-Simonians develop their vision of society as a body where each interdependent part has a specific task. This provides intellectual fertile ground for their economic theory. This is supplemented by a deterministic framework which presupposes the existence of laws in history. The most fundamental of these laws is that of the perfectibility of the human spirit (loi de perfectibilité de l'esprit humain): ${ }^{3}$ everything is progressing towards happiness. From this perspective, the human institutions are merely tools designed to further happiness as a goal. Saint-Simon's own work, as well as the positivism initiated by Auguste Comte, are thus seen as contributions towards this goal. Through the various stages of society, the human mind is always improving, helped always by the institutions designed by them and for them. In short, the Saint-Simonian doctrine is a philosophy based upon physiology and the idea of the unavoidable and unlimited progress of the human mind.

Hence, society should favor economic, intellectual and social progress - although this has not always been the case: the study of history also reveals a process of alternation between organic and critical periods. During a critical period, society can only be seen as a sum of individuals pursuing their own interests: no unity or harmony can emerge. More precisely, the Saint-Simonians see a strong opposition in society between idlers and producers: the former only consume without producing, while the latter only work and try to improve its social conditions. This antagonism is the principal characteristic of a critical period. An organic period is one which gives birth to the real society: a social institution whose structures reflect the mutual interests of the individuals which comprise it, and where this harmony is maintained by hierarchy and social order. In the Saint-Simonian view, the critical state destroys the organic one: for instance, the Greek philosophy and, later, the Protestant Reformation, destroyed the organic state built by Greek polytheism and the Christian Church. While the French Revolution - forming part of another critical period - is seen as having reflected a need for new institutions, the Saint-Simonians try to develop a new framework which is able to bring individual interests into harmonious association. In such a framework, new organic periods would be achievable by collective action. Free competition and laissez-faire - the cornerstones of individualism - are elements

\footnotetext{
${ }^{2}$ We draw these formulations of the maxims from Iggers 1972, p. xxxix.

${ }^{3}$ All quotations from Le Producteur and the Revue Encyclopédique are translated by the author.
} 
of the critical period that they aim to bring to an end. The outdated system, therefore, has to give way to a new one. The French Revolution failed as a step towards a new period of progress and simply replaced individuals by other individuals within the same institutions. Indeed, in Saint-Simonianism this revolution is seen as a proposed remedy for a social disease which should have given birth to a society free from social privilege. Unfortunately this wasn't the case: the inequalities persisted. This paves the way for the legitimation of a new system designed according to an improved economic doctrine.

\section{Saint-Simonianism as an economic doctrine?}

The Saint-Simonian doctrine is sufficiently interesting to have attracted the attention of economists (Gilles Jacoud 2010). ${ }^{4}$ Many famous economists read the SaintSimonians as well as their master - for instance, Friedrich Von Hayek considered Saint-Simon as an "accoucheur d'idée" (Hayek [1941] 1964, p. 117). We might also note the important work by Elie Halévy in La Revue du Mois $(1907,1908)$, as well as that of Edgar Allix (1910) in his study of Saint-Simonianism in relation to the liberal and industrialist theorists Jean-Baptiste Say, Charles Dunoyer and Charles Comte. We should pay close attention to the full title of their first medium of communication: The Producer, Journal of Industry, Science and Fine Arts (Le Producteur, Journal philosophique de l'industrie, des sciences et des beaux-arts). This title manifests their willingness to establish a new order based upon three main types of workers (industrialists, scientists and artists), and thereby reach happiness. This journal sets out several considerations related to money, value and division of labor, but also makes observations on social conditions. The journal had more than twenty contributing writers, among which Barthélemy Prosper Enfantin appears as the major figure within the movement's economic strand.

The Saint-Simonians were young graduates, or workers contesting the fatalism of the period (economic crises, alternating political systems, the Napoleonic wars). To reach happiness, the Saint-Simonians appeal to the concept of association in order to link all the producers together. In the Saint-Simonian hierarchy, industrialists apply principles established by scientists while artists promote the Saint-Simonian project. The goal is not to let individual interests be freely matched by markets through the principle of laissez-faire and competition, but to end this anarchy by a rational organization of tasks and trades. Association refers to the convergence of material and intellectual interests between workers, and also implies concrete projects related to the condition of the working class: "the full association of the working class with industry would consist in including this class in profits of firms in which they participate, in exact proportion to each individual work involved" (Pierre-Isidore Rouen 1826, pp. 308-309). ${ }^{5}$ If order were well established, it would be possible to foresee events and therefore to achieve happiness. But this can be possible only where interests are aligned, and thus when a critical period gives way to a new organic period, an industrial one.

Here emerges another fundamental principle: that of industry. In its Saint-Simonian meaning, industry implies not only productive structure or economic progress as

\footnotetext{
${ }^{4}$ See the complete edition of the works of Saint-Simon in 2010 , and the digitization of the SaintSimonian texts on the scientific website of the Jean Monnet University.

5 "L'association complète de la classe ouvrière à l'industrie, consisterait à l'admettre aux bénéfices des entreprises auxquelles elle prend part, dans la proportion exacte de la mise individuelle de travail de chaque ouvrier".
} 
applied to machines, but also a concrete way of life. In other words, industry refers to progress added to happiness for all workers. We find pretty much the same idea in Say's Treatise, but the latter refuses to deal with notion of happiness inasmuch as political economy is only the science of consumption, repartition and distribution (Say [1803] 2006, p. 3). Moreover, it is fair to say that the Saint-Simonian concept of industry is too close to notions such as order that are discordant with the spirit of the Treatise. Notwithstanding these differences of definition, both believe in the capacity of their economic system to provide the means of subsistence for all members of their society, under the constraint that they should engage in improving the industrial infrastructure. In this respect, the controversy over gluts provides the perfect example to illustrate this convergence of views.

The controversy over commercial gluts marks an entire era in history of economic thought. At its root, this controversy concerns the attempt to understand the mismatch between demand and supply on markets - or channels (canaux), in Say's writings - in Europe from 1815 to 1825 . More precisely it may be narrowed down to a simple question: Is a general overproduction possible? While Sismondi and Malthus see the economy as characterized by both general overproduction and underconsumption, Say on the contrary sees undersupply as confined to only a few channels. Sismondi's New Principles of Political Economy $(1819,1827)$ can be seen as the first step through which new elements emerged with respect to this controversy which differed from the analysis provided by the Smithian framework. Sismondi reasons in terms of the ratio between wealth and population. Once he has accepted the necessity of using this ratio, Sismondi develops an analysis of excesses of production which bears in mind the level of population and available wealth. Malthus adopts pretty much the same analysis and thereby demonstrates that general overproduction exists. In his Principles of Political Economy, therefore, Malthus is thus directly confronting Say and Ricardo and accusing them of considering population as the only necessary stimulus to increase wealth. Hence, Sismondi and Malthus refuse to accept that "a product is no sooner created than it, from that instant, affords a market for other products to the full extent of its own value" (Say [1803] 2006, p. 251).6 A dispute between Say and Sismondi then arose in La Revue Encyclopédique. To the present study we may also add to the Treatise some extracts from Say's article entitled "Sur la balance des consommations avec les productions" (1824). The Saint-Simonians never participated directly in this controversy, but, analyzing Say and Sismondi's points of view in several articles from Le Producteur, they reveal that they agree with Say not only on the causes of these gluts but also on the necessary remedies.

\section{Commercial gluts and lack of industry}

The Saint-Simonians as well as Jean-Baptiste Say both consider that these commercial gluts are due to an inability to exchange commodities. This inability is highly correlated with the fact that some sectors of production lack the means to produce, whereas too many commodities are provided in some other channels. Here, we show that Jean-Baptiste Say and the Saint-Simonians both emphasize the lack of mobility of the instruments of production and commodities, which is strongly linked with a more general failure: that industry fails to bring about fluid economic activity.

\footnotetext{
6 "Il est bon de remarquer qu'un produit terminé offre, dès cet instant, un débouché à d'autres produits pour tout le montant de sa valeur".
} 


\section{Sectorial and geographical mobility}

The Saint-Simonians and Say assert that one of the major causes of gluts is the lack of mobility in markets. Hence they observe that "we don't produce too much, production doesn't go where it needs to be" (Say 1824, p. 427), ${ }^{7}$ showing that the question is one of the mobility of the instruments of production and the final goods. In the Treatise, gluts are due to a dearth of commodities. Some markets are undersupplied, according to his famous law on outlets. Some commodities stay unsold because other commodities remain unproduced. It is upon this basis that we link Say with the SaintSimonians: both think that the problem is that markets are undersupplied:

Lack of sale of a commodity, or even of a large number of products, is the result of a gluts in one or more channels of the industry; in these channels, the quantity of supplied commodities exceeds demand from general needs, and this is always due to other channels, which far from being congested, are lacking several products ... this is because production of missing commodities suffered, that the superabundant commodities find no outlet. ([1803] 2006, pp. 250-252)

Hence, Say maintains, the most important challenge is to find a buyer, which in this particular case remains difficult: this is due to "political or natural convulsion, or the avarice or ignorance of authority" (Say 1824, p. 253). ${ }^{9}$ Indeed, as a disciple of Adam Smith and laissez-faire, Say deeply believes in the capacity of a market to provide goods to all members of a given society. As shown before, the Saint-Simonians also stand against the avarice or ignorance of authority, considering that new institutions have to be created in order to improve social conditions. More precisely, they place their trust in a reorganization of society and production. In this they join Say in the belief that some inept public authority has interfered with production - and given birth to gluts - but, unlike Say, their views are embodied in a historical analysis of social change and a search for new structures of authority.

Another way to analyze the Saint-Simonian view is to emphasize the role played by idleness: the Saint-Simonians strongly believe that happiness can be reached once idlers become producers. In other words, they argue against those who keep financial means for themselves or invest in useless projects at a time in which the entire world needs an association of able producers. Seen in this light, one of the major causes of commercial gluts is structural: it is due to the idlers' propensity to save at a time when the need for investment is more necessary than ever. The Saint-Simonians observe that some of the required financial resources remain locked in idle hands as some renters keep these means outside of the production system. This shows a lack of ability on the part of the idlers, who fail to see where the social interest lies and fail to grasp the industrial imperatives. It is then that commercial crises occur, as some sectors of production lack the means to finance their production. This is why production is "misunderstood" rather than "too much abundant" in Europe (Jacques-Julien

\footnotetext{
7 “On ne produit donc pas trop ; mais la production ne va pas où elle devrait aller".

8 "Un défaut d'écoulement d'un produit, ou même d'un grand nombre de produits, n'est que le résultat d'un engorgement dans un ou plusieurs des canaux de l'industrie ; qu'il se trouve alors dans ces canaux une plus grande quantité de ces produits que n'en réclament les besoins généraux, et que c'est toujours parce que d'autres canaux, loin d'être engorgés, sont au contraire dépourvus de plusieurs produits ... c'est parce que la production des produits manquants a souffert, que les produits surabondants ne trouvent point de débit".

9 “Désastres naturels ou politiques, l'avidité ou l'impéritie des gouvernements".
} 
Dubochet 1826 b, p. 322$)^{10}$. This point of view clearly has intellectual affinities with Jean-Baptiste Say.

The lack of mobility concerns not only different sectors but also different geographical areas. In other words, commercial crises are due to geographical imbalances: some products and instruments of production fail to reach some countries. Say focuses on the domestic market as he believes that it provides the outlets that are the most able to avoid gluts: "progresses of domestic industry are sufficient to explain domestic outlets" (Say 1824, p. 30); ${ }^{11}$ and Say also remarks that international trade "has on the prosperity of a State, a smaller influence than is commonly admitted."12 Domestic economic activity is supposed to be more pertinent than trade in this particular case: for instance, prosperity in England is supposed to be due more to its domestic industry than its maritime supremacy.

Finally, the geographical aspect of gluts has here to be taken into consideration, even though it remains secondary in as much as the concept of sector - or channels still appears as the cornerstone of Say's reasoning. As we noticed, geographical aspects are important in the Saint-Simonian theory. Here we see the necessity to increase the mobility of commodities, as "it is not in the abundance of things produced that we can see evil, but in their poor distribution" (Dubochet 1826a, p. 98). ${ }^{13}$ The underlying idea is that production lacks mobility in the sense that some markets are undersupplied. This can be explained by the fact that, as we saw, the Saint-Simonians attach great importance to physiology in their theory of society. On this basis, commercial gluts are a barrier to this flow, just as a clot prevents a body part being adequately supplied with blood. Although this metaphor may seem trivial to modern readers, it remains the case that the Saint-Simonians see society as like a body in which each individual is assigned a particular function. Hence the Saint-Simonians and Say use different reasoning but share the same views on the causes of gluts: some markets are undersupplied.

\section{Industrial infrastructures and ability}

Another related element for explaining gluts is the lack of infrastructure. Better organization of production leads to improvements in the instruments of production, and underscores the necessity of increasing the capacity of an economic system to provide consumption goods across a given territory. This is part of a willingness to see industry - as savoir-faire but also as infrastructures - being developed in all sectors of production. Enfantin argues that problems arise from sudden population movements, notably soldiers returning from the Napoleonic wars: "we produced more grains, more sheets, more wines, etc., and yet the population was the same, the production processes were not yet perfected ... finally commodities, finding no buyers, degraded and prepared an inevitable crisis" (Enfantin 1826c, p. 393). ${ }^{14}$ Enfantin teaches us

\footnotetext{
10 “On a pu voir les déplorables effets d'une production non pas trop abondante mais mal entendue, dans la crise générale où se trouve l'Europe industrielle, et particulièrement l'Angleterre".

11 "Les progrès de l'industrie intérieure suffisent pour expliquer l'extension des débouchés de l'intérieur".

12 “Le commerce extérieur exerce sur la prospérité d'un État une bien moins grande influence qu'on ne le croit généralement".

13 “Ce n'est donc pas dans l'abondance des choses produites qu'il faut voir le mal, mais bien dans leur mauvaise distribution".

14 “On a produit plus de grains, plus de draps, plus de vins, etc., et cependant la population était la même ; les procédés de production n'étaient pas encore perfectionnés ... enfin les produits, ne trouvant pas d'acheteurs, s'avilissaient et préparaient une crise inévitable”.
} 
clearly that industrial activity is hard to organize because of a lack of infrastructure, especially those pertaining to industry. And the idea of the improvement of production processes (including communication networks) should be linked with several works by Auguste Decaen in Le Producteur on industrial projects such as fluvial towing or dredging (Decaen 1825a, 1825b). Hence, as Jean-Baptiste Say also notices: gluts arise "from one industry too dimly lit, too quite progressed" (Say 1824, p. 27). ${ }^{15}$

The lack of infrastructure leads us to consider another related problem: the industrialists' lack of knowledge. According to both doctrines, the producers miscalculate their levels of production. There is thus also a lack of ability, particularly cognitive ability. Although this concept of ability is largely unknown in Say's works, it should nonetheless be noted that he did adopt views that show intellectual affinities with the Saint-Simonian concept. Hence Say uses the notion of faculty, which is also closely linked to industry. His definition of "productive faculty" (from the 3rd edition, 1817) refers to the "ability of the industrious capitalists and natural agents to cooperate in the production by giving a utility to things" (Say [1803] 2006, p. 1100). ${ }^{16}$ Say demonstrates that gluts appear as soon as industrialists make mistakes about their production levels, because some of them lack knowledge and skills. Hence, a "glut of a particular commodity arises ... because it has been produced in excessive abundance, or because the production of other commodities has fallen short. It is because the production of some commodities has declined, that other commodities are superabundant" (Say 1824, p. 253). ${ }^{17}$

This shows that gluts are also due to miscalculations, which are related to the quantity of commodities that will be exchanged against other commodities: relative excesses of production in other sectors create a gap between supply and demand. Hence Say states that another cause of commercial crises - added to political and natural convulsion - is a lack of industry on the part of producers: "this glut, when it takes place, is the effect of miscalculations from producers" (Say 1824, p. 27). ${ }^{18} \mathrm{We}$ find exactly the same idea in Saint-Simonianism: Enfantin observes that "temporary gluts of certain goods carries disorder in markets" when "the enterprising men ... miscalculate the ratio of production to consumption" (Enfantin 1826c, p. 392). ${ }^{19}$

Here emerges the necessity to educate workers in a way which allows the free expression of ability and so avoid this kind of market failure: education must comply with industrial requirements and assign to each individual a particular task "by accustoming since childhood to voluntary subordination of particular interest to the common good" (Auguste Comte 1826, p. 362). ${ }^{20}$ In both cases, the analysis deals with the idea of the incompetence of some members in a given society. Since incompetence is at issue, ability and faculty are therefore important concepts in both doctrines. Whereas Say's considerations are related to a specific situation without calling into question the economic system, those of the Saint-Simonians are designed in terms of structure and they advanced criticisms against a certain model of society. Thereby we

\footnotetext{
15 “C'est-à-dire, d'une industrie trop peu avancée".

16 "L'aptitude qu'ont les industrieux, les capitalistes et les agents naturels, à coopérer à la production en donnant aux choses de l'utilité".

17 "Des marchandises ne se vendent pas, ou qui se vendent à perte ... parce qu'on en a produit des quantités trop considérables, soit plutôt parce que d'autres productions ont souffert. Certains produits surabondent, parce que d'autres sont venus à manquer".

18 “Cet encombrement, quand il a lieu, est l'effet des mauvais calculs des entrepreneurs".

19 "Des hommes entreprenans qui calculent mal le rapport de la production avec la consommation, et l'encombrement momentané de certains produits porte le désordre dans les marches".

20 "En habituant dès l'enfance à la subordination volontaire de l'intérêt particulier envers l'intérêt commun".
} 
find the same idea of lack of industry in the assertions of Say and the Saint-Simonians. We turn now to analyze their proposals for ending these crises, in order to discover whether Say and Enfantin adopt the same views in this respect as well. These commercial crises are in fine crises of production, more precisely of underproduction. Thus a clear solution appears in both doctrines: increasing production by improving industrial infrastructure and increasing the number of industrious workers.

\section{The necessity of increasing production}

Our inquiry into the causes of commercial gluts as set out in Saint-Simonianism and the work of Jean-Baptiste Say has shown clearly that these two doctrines are linked. Their common emphasis on a failure of mobility and a lack of infrastructure shows their point of convergence. However, we could now go one step further: the SaintSimonians and Say both believe that if the economic system succeeds in providing adequate instruments of production and adequate means of transporting final goods toward all parts of the territory in question, these gluts will be avoided.

\section{Increasing production (1): Say’s law}

Say admits that commercial channels can be blocked and that production could exceed demand, but maintains that this would involve only a few channels, and could only happen temporarily: inasmuch as commodities are sold against other commodities, Say argues, all channels cannot be blocked at the same time. Here a complicated issue arises concerning Say's reasoning: in the first edition of his Treatise, Say refers to the concept of commodities as final goods, but during the controversy with Malthus and Sismondi he defines a final good as a sold good: "a commodity which does not reimburse the cost of production, that is to say a commodity whose market value does not pay profits and wages ... is not a commodity, it is the result of inert waste of time" $\left(1824\right.$, p. 28) ${ }^{21}$ Say identifies the utility of these commodities with their value: if the cost of a commodity exceeds its selling price, then we cannot assert that the commodity is useful. This is not the case for the Saint-Simonians, who employ the notion of utility but also deeply believe that value emerges from the soil by work. Indeed, in Saint-Simonianism, each able individual has to be useful - that is to say, workers have to contribute to production. Where the cost of a commodity exceeds its selling price, the Saint-Simonians maintain only that the producer lacks industry in the sense of knowledge. Thus their definition of a commodity differs. The SaintSimonians respect the Classical framework, while Say adopts a new value theory, one which will pave the way for neo-Classical economics.

However, Say argues, the existence of poverty in the streets shows clearly that general overproduction cannot arise. Moreover, insofar as it does arise, it only concerns a short period of time, because free competition is able to ensure equilibrium between supply and demand: a "glut of a particular commodity arises ... because it has been produced in excessive abundance, or because the production of other commodities has fallen short" (Say [1803] 2006, p. 135). ${ }^{22}$ The problem of gluts

\footnotetext{
21 “Un produit qui ne rembourse pas ses frais de production, c'est-à-dire un produit dont la valeur vénale ne paie pas les profits et les salaires indispensables pour le mettre au point de satisfaire les besoins quels qu'ils soient des consommateurs, n'est pas un produit ; c'est le résultat inerte d'une peine perdue".

22 "Des marchandises ne se vendent pas, ou se vendent à perte ... parce qu'on en a produit des quantités trop considérables, soit plutôt parce que d'autres productions ont souffert. Certains produits surabondent, parce que d'autres sont venus à manquer".
} 
therefore has a solution: a better circulation of production across the country. In this respect, it appears possible to remedy this economic evil. This is why there is a dimension of the fluidity of production in the writings of Say, who praises the "fluidity that provides a more active industry and a cheaper production" (Say 1824, p. 28). ${ }^{23}$ It follows, by implication, that increasing production is not a problem but a solution: "always it is true that, till now, the commodities that are most easily multiplied were also those which are most easily sold" (Say 1824, p. 25). ${ }^{24}$ The demand for commodities must be created thanks to other production. Hence, in order to increase the quantity of commodities afforded on markets, it remains necessary to have fluid and sustained economic activity: "countries where expeditious methods are best known and commodities most increased, as the most industrious provinces of England ... are also the richest, or, if you want, the less miserable" (Say 1824, pp. 20-21). ${ }^{25}$

Economic activity can be sustained in the long run by fluid production. This is all about the skills of producers, who must learn about political economy. Say was deeply convinced that entrepreneurs were at the heart of the economic system. Being an entrepreneur is not easy, and requires talents, skills and knowledge - that is to say industry as savoir-faire. In this respect, these entrepreneurs have to "create commodities that might suit their consumers" and "sell it at a price that facilitates consumption" (Say 1824, p. 27). ${ }^{26}$ Moreover, gluts are also due to consumers: "if consumers were industrious enough to offer exchange objects, gluts would end" (Say 1824 , p. 27). ${ }^{27}$ Therefore it is no longer only down to producers to be industrious, but also to consumers, although Say unfortunately doesn't specify how consumers can actually be more industrious. Finally, it is clear that Say's liberal views run contrary to the Saint-Simonian project of association: "why the task of associating interests of those who contribute to the same production, instead of putting them in opposition ... I would rather call him to the legislator or the administrator whenever a barge come into a shop, to interpose between the merchant and the buyer" (Say 1824, p. 29). ${ }^{28}$ However, Say is favorable toward entrepreneurship, and this is why he seems close to the Saint-Simonians. Indeed, by their emphasis on industrial projects and bank credit, the Saint-Simonians agree with Jean-Baptiste Say on the necessity of driving movement in economic activity.

\section{Increasing production (2): the role of bank credit}

The primary purpose of the Saint-Simonians is to maintain fluidity in the economic and industrial system according to each person's ability: "the great problem of the circulation is to achieve, as promptly as possible, the commodities in the hands of men

\footnotetext{
23 "L'aisance que procure une industrie plus active et une production moins chère".

24 “Toujours est-il vrai que, jusqu'à présent, les produits qui se sont le plus facilement multipliés ont aussi été ceux qui se sont le plus facilement écoulés".

25 "Les pays où les procédés expéditifs sont plus connus et les produits plus multipliés, comme les provinces les plus industrieuses de l'Angleterre ... sont aussi les plus riches, ou, si l'on veut, les moins misérables".

26 "Créer des produits qui pussent convenir à leurs consommateurs ... les établir à un prix qui en facilitât la consommation".

27 "Si les consommateurs étaient assez industrieux pour offrir de leur côté des objets d'échange, cet encombrement cesserait, et se résoudrait en moyens de prospérité".

28 "Pourquoi donc la tâche d'associer les intérêts de ceux qui concourent à la même production, au lieu de les mettre en opposition, appartient au législateur ? Comme si l'économie de la société toute entière ne roulait pas sur des intérêts qui se débattent entre eux ! J'aimerais autant qu'il appelât le législateur ou l'administrateur, chaque fois qu'un chaland entre dans une boutique, à s'interposer entre le marchand et l'acheteur'.
} 
who are most able of improving it or at least use them directly or indirectly to their work" (Enfantin 1826d, p. 41). This fluidity needs new infrastructure: roads, canals, and so forth: "these gluts of commodities and workers could be avoided, at least for the most part, if there were easier ways of communications, faster and more economical than actual means" (Dubochet 1826a, pp. 98-99). ${ }^{29}$

Free competition has proved its worth and was adequate for older systems, but, according to the Saint-Simonians, it is time to give way to association. As the concept of association is related to the convergence of material and intellectual interests between workers, the Saint-Simonians choose to provide for this convergence by appeal to bank credit. Hence, bank credit is not only a financial link between several economic actors but also a way to improve their social condition. More precisely, the Saint-Simonians aim to enable each worker to access the instruments of production. They observe that a large amount of capital is in idle hands, while inequalities and impoverishment are growing. Hence a transfer appears clearly necessary, and bank credit remains the solution. In their project of association, each able producer has a right to the portion of the instruments of production inasmuch as producing enables the improvement of social conditions of all members of this association. Thus we see here that bank credit isn't only a concept relating to economic operation, but also has more social and philosophical aspects, and indeed stands at the basis of association. Credit, therefore, should be seen as a cornerstone of the system inherited from SaintSimon, who taught that society could not persist without credit. This is why unlimited competition must give way to the association.

However, we must draw particular attention to a constraint: in opposition to certain kinds of speculation, the production provided by the association has to be industrious. In other words, it has to serve the public interest. Indeed, association presupposes that each producer performs his or her tasks in accordance with the imperative of industry and the improvement of social conditions. To this end, a better circulation of production - via bank credit - is necessary: first, "if relationships between men who possess the commodities and those who claim it are likely to offer this work facility", and secondly "if capital, inactive or incorrectly used, passes quickly in laborious and skillful hands, under the condition to give it back when the work is completed", then it would come about that "the traffic problem would be completely solved because capital would be always used as much as possible, without the lender, during all working hours, interfering by claiming reimbursement from the producer" (Enfantin, $1826 \mathrm{~d}$, p. 49) ${ }^{30}$ By implication, credit is a great way to avoid frictions in the market, in the sense that credit can unlock the untoward economic conditions of the time. Hence, these crises are by no means inevitable:

The movement of commodities, in addition to physical barriers ... always fights against an obstacle which may be called moral, the distrust, whose inconveniences can be reduced: when the workers approach the owner of the commodities they need, ... when the producer is in the presence of the owner, if he momentarily doesn't need

\footnotetext{
29 “Ces encombremens de produits et de travailleurs pourraient être évités, du moins pour la plupart, s'il existait des moyens de communications plus faciles, plus rapides et plus économiques que les moyens actuels".

30 "Si les rapports entre les hommes qui possèdent les produits et ceux qui les réclament étaient de nature à offrir cette facilité de travail ; si les capitaux, inactifs ou mal employés, passaient avec rapidité dans des mains laborieuses et habiles, sous la condition de ne les rendre que lorsque le travail serait achevé, le problème de la circulation serait complétement résolu puisque les capitaux seraient toujours employés le mieux possible, sans que le prêteur, pendant toute la durée du travail, pût gêner le producteur en réclamant le remboursement".
} 
those commodities and if he has trust in the promise of repayment offered by the producer, he delivers him the instruments of industry in his possession ... facilitating the movement is therefore bringing trust as far as possible from idle people to workers. (Enfantin 1826d, p. 50) ${ }^{31}$

Hence, by credit, the Saint-Simonian association aims to "provide support to the branches of the most productive industry, that is to say, the ones which provide mostly at the general good" (Rouen 1825, p. 15). ${ }^{32}$ For this purpose, bankers have to refuse credit to companies that do not meet this criterion of the general good. Bankers are at the head of the Saint-Simonian system and have to respond to a clear imperative: only industrious projects have a right to the instruments of production. In this respect, all "companies depending on privileges or living in immorality" will be denied that trust (Rouen 1825, p. 15). ${ }^{33}$ We find this notion of privilege again when the SaintSimonians teach us that "the developments of the principle of association must have the constant result of reducing the influence of this privilege, allowing day workers to determine the conditions of rest, as the idle people still set today's working conditions" (Enfantin 1825, p. 247). ${ }^{34}$

Finally, Jean-Baptiste Say explains that there is a need to produce other commodities to provide a means of exchange. By implication, each producer would be able to exchange with other producers. We find the same idea in Saint-Simonianism: we need to increase production - helped by bank credit - as a means to avoid overproduction. In other words, they both call for more industry and mobility. Thus, on the question of gluts, the Saint-Simonians and Jean-Baptiste Say show a striking affinity, and by the same measure they differ significantly from the concerns raised by social thinkers such as Sismondi or Fourier. Consequently, we shall focus on the fact that the Saint-Simonians appear close to Jean-Baptiste Say on this matter, and we go on to argue that the explanation for this is to be provided by reference to the influence of the Smithian framework in France.

\section{Jean-Baptiste Say and the Saint-Simonians: two neo-Smithian doctrines}

The theory of political economy developed by the Saint-Simonians remains a neoSmithian doctrine, just as much as that of Jean-Baptiste-Say: they have, each in their way, built upon a common legacy. In that sense, the Saint-Simonian doctrine appears close to considerations developed by Say related to the role played by industry. It is upon this basis that we can explain affinities shown above.

\footnotetext{
31 "La circulation de produits, outre les entraves matérielles ... lutte donc toujours contre un obstacle qu'on peut appeler moral, la défiance, dont il est possible de diminuer les inconvéniens : lorsque le travailleur s'est rapproché du possesseur des produits dont il a besoin ... lorsque le producteur est en présence du propriétaire, si celui-ci peut se passer momentanément de ses produits et s'il a confiance dans la promesse de remboursement que lui offre le producteur, il lui livre les instrumens d'industrie qu'il possède ... faciliter la circulation, c'est donc porter aussi loin que possible la confiance des oisifs dans les travailleurs".

32 “Ainsi, l'association doit forcément prêter son appui aux branches de l'industrie les plus productives, c'est-à-dire qui vont le plus au bien général".

33 "Aux entreprises qui vivent de privilèges ou d'immoralité".

34 "Les developpemens du principe d'association doivent en effet avoir pour résultat constant de diminuer l'influence de ce privilège, en permettant un jour aux travailleurs de détermine les conditions du repos, comme les oisifs fixent encore aujourd'hui les conditions de travail'".
} 


\section{Smith as a master in both doctrines}

Links between Smith and Say are well known. Alain Béraud, Jean-Jacques Gislain and Philippe Steiner (2004), for instance, have shown that Say's writings are based upon Smithian reasoning in at least two respects: a distinction between political economy and politics, and the primacy of observation in science. Since these two points have already been discussed in the literature, we aim here only to shed light on the SaintSimonian doctrine: ${ }^{35}$ we argue that in their own theories the Saint-Simonians and Say incorporate elements from Smith's writings. It is quite obvious that most economists at the beginning of the nineteenth century were inspired by Smith, but Say remains the economist who was most able not only to clarify the Smithian doctrine but also to bring in new elements such as utility-in-value. Meanwhile, the Saint-Simonians were among the few theorists able to base their criticism of property rights on the famous classical triptych wages-rent-profit. Finally, even though the same strands of the Smithian doctrine do not inspire the Saint-Simonians and Say, they both clearly fall under the scope of the Smithian framework.

Concerning observation as a scientific method, it is interesting to note that SaintSimon and his school share the views of Say (and therefore Adam Smith, from whom they all learned). Indeed, the Saint-Simonians recognize observation as the only method able to provide scientific knowledge, even though economists themselves largely ignored this doctrine. It is mostly through the influence of Auguste Comte in Saint-Simonianism that observation became widely discussed and came to be seen as the basis of sensualist philosophy and positivism. This in turn may be due to several factors: first, observation is often linked with Comte's positivism, who often overshadows his own master in this field. Perhaps it is also due to the particular positions adopted by the Saint-Simonians as against other thinkers, such as the eclectic school of Victor Cousin (1792-1867) and the Cartesians. For instance, in their willingness to see observation as the only scientific method, the Saint-Simonians accuse these other streams of thought of assigning too much of a role to abstraction (see, for instance, Paul-Mathieu Laurent 1826a, 1826b). (Nevertheless, we may note in passing that Cousin also proposed an experimental method based upon observation and history, and levelled against the Cartesians the same accusations as the SaintSimonians (1855[1826], pp. 5-7).) However, the Saint-Simonian doctrine - the positive school - is based upon observation, just as in Say's Treatise.

Focusing on the economic strands in both doctrines, we have cause to observe that the Saint-Simonians do in part take up ideas from Adam Smith: concerning the nature of wealth, labor value and capital accumulation. Moreover Say and the SaintSimonians improve upon the Smithian doctrine in at least two respects: money and industry. This indicates clear affinities between the two doctrines, which need to be illuminated. One improvement provided by Say as compared to the Smithian framework is his concept of money as a mere vehicle. Say's contributions to monetary theory have been widely studied (see, for instance, Jean-Pierre Potier and André Tiran 2003). The monetary analysis developed by Say serves as a basis for his reasoning on gluts. It is worth recalling this framework and the influence it exercised on the SaintSimonians. Say reasons at a global level where the demand for money is equal to the supply of money. The price is an equilibrium between the same two-faced action: sales and purchases. On money (albeit only in relation to trade), Saint-Simonianism appears as a rejoinder to Say. The most interesting element linking these authors is that they all

\footnotetext{
${ }^{35}$ See also Bernard Boureille and Abdallah Zouache (2010).
} 
consider money as a vehicle of value issued by a "need to facilitate trade" (Enfantin 1826b, p. 78). ${ }^{36}$ In this, the Saint-Simonians are deeply influenced by Say. Hence, another Saint-Simonian, Adolphe Blanqui, here in the context of commenting on the books of the statistician Alexandre Moreau de Jonnès, teaches us that "everyone knows now that we obtain money only through commodities, and that ultimately, buying commodities with money is always buying commodities with commodities, and consuming a true exchange" (Blanqui 1826, pp. 308-309). ${ }^{37}$ This is strongly correlated with the famous point of view expressed by Say concerning money and trade: "money performs but a momentary function in this double exchange; and when the transaction is finally closed, it will always be found, that one kind of commodity has been exchanged for another" (Say [1803] 2006, pp. 248-250). ${ }^{38}$ Moreover, Enfantin goes further by considering money as engendering real progress in trade, in the sense that it increases the number of transactions. This improvement is seen by Enfantin in the same light as infrastructure born from industrial progress: "as well as in the construction of roads, canals and ships that bringing people closer" (Say [1803] 2006, p. 309). ${ }^{39}$ Finally both Jean-Baptiste Say and the Saint-Simonians see money as a vehicle, and insist on the fluidity of production. The only difference here concerns the role played by money in their economic system. Although the Saint-Simonians see money as a commodity, they also think that money isn't neutral. This clearly goes against the views from the Treatise. Notwithstanding this difference, they all build their reasoning on the key idea of industry, which is a complex notion and not easy to apprehend. We shall discuss their views on this concept in the light of two doctrines that can be described as "industrialist."

\section{Two industrialist doctrines}

Saint-Simon defines industry as the "ability to produce things of material value" (Saint-Simon 2012(4), p. 2836). ${ }^{40}$ The concept of industry is highly correlated with the concepts of ability and utility. The latter concept does not have a link with utilitarianism, as they use it in its first and literal sense: what is useful. The SaintSimonian concept of ability, upon which the rules of distribution and allocation of goods are based, refers to the complete use of their skills by individuals. Being able, therefore, means being useful to industry. The difference from Say lies in the fact that the Saint-Simonians add the notion of an imperative as related to society. That is why they aim to hierarchize individual tasks. Clearly, Jean-Baptiste Say never reasons in these terms, as any notion of hierarchy or order regarding economic activity is to be subsumed under laissez-faire. It is industry - more than utility - that is able to connect these two doctrines, as evidenced by the discussions between liberal and industrialist authors inspired by Say (Le Censeur Européen) and the Saint-Simonians (Le Producteur) concerning the definition and paternity of this movement. ${ }^{41}$ Linked with

\footnotetext{
36 "Faciliter les échanges".

37 “Chacun sait, à présent, qu'on n'a de l'argent qu'avec des produits, et qu'en définitive, acheter des produits avec de l'argent, c'est toujours acheter des produits avec des produits, et consommer un véritable échange".

38 “L'argent ne remplit qu'un office passager dans ce double échange; et les échanges terminés, il se trouve toujours qu'on a payé des produits avec des produits".

39 "Aussi bien que dans la construction des routes, des canaux et des navires qui rapprochent les peuples".

40 "La capacité de produire des choses d'une utilité matérielle".

${ }^{41}$ See Dunoyer and his historical analysis of industrialism (1827) and the answer made by the SaintSimonians (1827). See also Gareth Stedman-Jones (2006).
} 
idea of progress, industry is an integral part of these two doctrines. Say and the SaintSimonians both attach central importance to these two notions in their writings. It is in this sense that they improve upon the doctrine of Adam Smith, except that Say remains confined to the narrow study of "the manner in which wealth is produced, distributed, and consumed" (Say [1803] 2006, p. 3). ${ }^{42}$

Jean-Baptiste Say frames his views in relation with economic progress and industry, whereas the Saint-Simonians design a whole doctrine of social change based upon industry and association. Indeed, the separation that Say insists upon between political economy and politics in a broadest sense, leads him to not specify any "goal, which needs to be assigned to his organization, or even if the organization need to have a goal" (Charles Dunoyer 1827, p. 370). That is why the Censeur Européen tries to provide a political strand to the liberalism espoused by Say, and above all a goal equivalent to the concept of happiness in the Saint-Simonian view. We should also note that there are economic considerations related to industry in Saint-Simonianism, which are linked to economic progress and industrial projects: machines should be part of the economic landscape since they improve the ability of the economic infrastructure to provide goods to all able workers. This role is decisive to understand their position on the controversy over gluts.

Moreover, the concept of industry as it appears in Say is not purely economic, as the Treatise sheds light on the beneficial effects of industry, and not only in its various economic strands. As also shown by Edgar Allix (1910), the notion of industry is treated in more than purely economic considerations, as seen in certain specific passages: "each individual is interested in the general prosperity of all, and ... the success of one branch of industry promotes that of all the others" (Say [1803] 2006, p. $254) .{ }^{43}$ Hence, "the position of a nation, in respect of its neighbors, is analogous to the relation of one of its provinces to the other, or of the country to the town; it has an interest in their prosperity, being sure to profit by their opulence" (Say [1803] 2006, p. 255). ${ }^{44}$ Thus, industry is not a mere economic concept in the Treatise; it improves life in society and embodies more general considerations.

The Saint-Simonians refuse to use the term "industrious" in the manner of Say. Indeed, a controversy arises between Dunoyer and the Saint-Simonians about the use of the terms "industry" and "industrious". The Saint-Simonians reproach Dunoyer of defining "industrious" without speaking about bankers and merchants (Say includes merchants in his typology (Say [1803] 2006, p. 1122)). The concept of industry here entails several notions, such as "either a class of citizens, or a group of ideas; in its application to persons, it designates both a productive ability and a political aptitude; it assigns clearly identified social rights and duties" (Saint-Simonian Collective 1827, pp. 11-12). ${ }^{45}$ This is not the case in the Treatise: there, an industrious individual is a scientist, a farmer, a manufacturer, a merchant or a laborer. Moreover, Say defines "industry" only in a narrow economic sense: industry is the "application of our human faculty" (Say [1803] 2006, p. 1122). ${ }^{46}$ This presupposes knowledge about laws of

\footnotetext{
42 "Comment les richesses se produisent, se distribuent et se consomment".

43 “Chacun est intéressé à la prospérité de tous, et que la prospérité d'un genre d'industrie est favorable à la prospérité de tous les autres".

44 "Une nation, par rapport à la nation voisine, est dans le même cas qu'une province par rapport à une autre province, qu'une ville par rapport aux campagnes: elle est intéressée à la voir prospérer, et assurée de profiter de son opulence".

45 "Soit une classe de citoyens, soit un ensemble d'idées; dans son application aux personnes, il désigne, tout à la fois, une capacité productive et une aptitude politique; il assigne des droits et des devoirs sociaux clairement déterminés".

46 "L'application des facultés humaines".
} 
nature and their application to create utility. These different types of industrious producer are distinguished within a hierarchical order: and capitalist and owner come at the end of this list, as they don't really produce utility, and this is why they are not seen as industrious. This is much the same as in Saint-Simonianism; capitalists are idlers, just as are the renters. Added to the fact that Say regards ownership in a poor light - seen as the less honorable kind of property and linked with notion of spoliation (Say [1803] 2006, p. 1143) - we can clearly see a convergence with SaintSimonianism. Hence, both doctrines disclose the same willingness to shape the improvement of industry.

\section{Concluding remarks}

A standard reading in the history of economic thought sets the classical stream of economists drawing upon the influence of Adam Smith (Jean-Baptiste Say, David Ricardo, Robert Torrens, etc.) in opposition to a black box of social thinkers (Blanqui, Sismondi, Owen, Godwin, Fourier). Here we have shown that Saint-Simonianism - as a physiologist philosophy - aims to build a society wherein each interdependent individual has to produce according to his or her task.

The elements of Saint-Simonianism are intended to enable us to design a complete economic system of industry, and this indeed appears close to that espoused in JeanBaptiste Say's Treatise. These points of affinity appear particularly clear concerning the controversy over commercial gluts, since the doctrines share the same view on their causes.

As a result, in both cases there emerges the same recommendation to increase production in order to provide the necessary commodities. In the case of SaintSimonianism, the industrial principles are employed to set up a hierarchy of abilities and tasks by using bank credit. In the Treatise, the goal is to ensure the fluidity of production based upon the famous Say's law, by improving the instruments of production. The arguments differ but the result - once again - is an intellectual convergence: that it is through an improvement of the industrial structures and the producers' skills that these gluts will cease.

Finally, according to their theoretical framework - both inspired in different ways by the thought of Adam Smith - we can observe two neo-Smithian doctrines, SaintSimonianism, and the French liberalism of Jean-Baptiste Say, which share the same goal: to enable an industrious system to emerge.

\section{References}

-Anonym 1826. "Le sol tremble, extrait de La Quotidienne." Le Producteur, journal de l'industrie, des sciences et des beaux-arts 2: 241-246.

-Ansart, Pierre. 1969. Marx et l'anarchisme: essai sur les sociologies de Saint-Simon, Proudhon et Marx. Paris: PUF.

-Allier, Joseph. 1826. "Prédominance de la doctrine positive sur les doctrines théologique et métaphysique." Le Producteur, journal de l'industrie, des sciences et des beaux-arts 2: 577-588.

-Allix, Edgar. 1910. J.-B. Say et les origines du libéralisme. Paris: Sirey.

-Béraud, Alain., Jean-Jacques Gislain and Philippe Steiner. 2004. "L'économie politique néo-smithienne en France (1803-1848)." Économies et Sociétés 38 (2): 325-418.

-Blanqui, Adolphe. 1826. "Du commerce au XIX $\mathrm{e}^{\mathrm{e}}$ siècle, par M. Moreau de Jonnès. (Troisième article)." Le Producteur, journal de l'industrie, des sciences et des beauxarts 2: 302-313. 
-Blaug, Mark. [1962] 1996. Economic theory on retrospect. Cambridge: Cambridge University Press.

-Boureille, Bernard., and Abdallah Zouache. 2010. "Influence de J.B. Say dans les écrits économiques des saint-simoniens (1825-1832)." In André Tiran, ed., JeanBaptiste Say : influences, critiques et postérité, Paris : Classiques Garnier, pp. 253270.

-Buchez, Philippe. 1826. "Physiologie de l'espèce. Des termes de passage de la physiologie individuelle à la physiologie de l'espèce humaine (Deuxième article)." Le Producteur, journal de l'industrie, des sciences et des beaux-arts 4: 416-433.

-Comte, Auguste. 1826. "Considérations sur le pouvoir spirituel (Troisième article)." Le Producteur, journal de l'industrie, des sciences et des beaux-arts 2: 358-376.

-Cousin, Victor. [1826] 1855. Fragments de philosophie contemporaine, Paris: Didier. -Decaen, Auguste. 1825a. "Cie des remorqueurs du Rhône, sous la direction de MM Séguin Frères d'Annonay." Le Producteur, journal de l'industrie, des sciences et des beaux-arts 1:34-44.

---------. 1825b. "Des avantages de la machine à draguer employée à creuser les canaux, etc." Le Producteur, journal de l'industrie, des sciences et des beaux-arts 1: 319-326.

-Dubochet, Jacques-Julien. 1826a. "Les routes à ornières de fer." Le Producteur, journal de l'industrie, des sciences et des beaux-arts 2: 97-109.

-------. 1826b. "De la speculation." Le Producteur, journal de l'industrie, des sciences et des beaux-arts 4: 317-335.

-Durkheim, Emile. 1928. Le socialisme : sa définition, ses débuts, la doctrine saintsimonienne. Paris: Alcan.

-Dunoyer, Charles. 1827. "Esquisse historique des doctrines auxquelles on a donné le nom d'Industrialisme, c'est-à-dire, des doctrines qui fondent la société sur l'Industrie." Revue Encyclopédique 23(2): 368-394.

-Enfantin, Barthélemy Prosper. 1825. "Considérations sur la baisse progressive du loyer des objets mobiliers et immobiliers (Premier article)." Le Producteur, journal de l'industrie, des sciences et des beaux-arts 1: 241-254.

--------. 1826a. "Réflexions sur quelques questions de douanes et de finances, discutées actuellement en France et en Angleterre." Le Producteur, journal de l'industrie, des sciences et des beaux-arts 2: 420-427.

-------. 1826b. "Considérations sur l'organisation féodale et l'organisation industrielle; comment l'esprit d'association se substitue graduellement dans les rapports sociaux à l'esprit de conquête." Le Producteur, journal de l'industrie, des sciences et des beaux-arts 3: 66-85.

1826c. "De la concurrence dans les sociétés industrielles." Le Producteur, journal de l'industrie, des sciences et des beaux-arts 3: 385-409.

-------. 1826d. "De la Circulation. Echange. Vente. Promesse. Produits. Monnaie. Papier." Le Producteur, journal de l'industrie, des sciences et des beaux-arts 4: 3767.

-Engels Friedrich; Marx Karl. [1848] 1952. Manifesto of the Communist Party. Chicago: Encyclopedia Britannica.

-Iggers, Georges. 1972. The doctrine of Saint-Simon: an exposition. First year, 18281829. New York: New York Schocken Books.

-Jacoud, Gilles. 2010. Political Economy and Industrialism: Banks in Saint-Simonian Economic Thought. Abingdon: Routledge.

-Halévy, Elie. 1907. "La doctrine économique de Saint-Simon." La Revue du Mois 6: 641-676. 
75.

1908. "La doctrine économique de Saint-Simon." La Revue du Mois 4: 39-

-Hayek, Friedrich August von. [1941] 1964, The Counter-Revolution of Science: Studies on the Abuse of Reason. Glencoe: The Free Press.

-Laurent, Paul-Mathieu. 1826a. "Fragmens philosophiques, par M. Victor Cousin." Le Producteur, journal de l'industrie, des sciences et des beaux-arts 3: 325-338.

--------. 1826b. "Fragmens philosophiques, par Victor Cousin (Deuxième article)." Le Producteur, journal de l'industrie, des sciences et des beaux-arts 4: 19-37.

-Potier, Jean-Pierre., and Tiran, André (eds). 2003. Jean-Baptiste Say. Nouveaux regards sur son oeuvre. Paris: Economica.

-Pribram, Karl. [1983] 1986. Les fondements de la pensée économique. Paris: Economica.

-Rouen, Pierre-Isidore. 1825. "Société commanditaire de l'industrie (Premier article)." Le Producteur, journal de l'industrie, des sciences et des beaux-arts 1: 11-20.

-Saint-Simon Henri. 2012. "Trois écrits sur la révolution européenne. Aux Européens" In Juliette Grange., Pierre Musso., Philippe Régnier., and Franck Yonnet, Henri SaintSimon. Euvres Complètes. 4 vols, Paris: PUF.

-Saint-Simonian collective. 1827. "Réponse des rédacteurs du Producteur à l'article de M. Dunoyer." Revue Encyclopédique 23 (3): 2-33.

-Say, Jean-Baptiste. [1803] 2006. Traité d'économie politique, ed variorum. 2 vols. Paris: Economica.

--------. 1824. "Sur la balance des consommations avec les productions." Revue Encyclopédique 23 (3): 18-31.

-Schumpeter, Joseph. [1954] 2006. History of economic analysis. Abingdon: Routledge.

-Sismondi, Jean-Charles-Léonard. [1827] 1991. New principles of political economy, of wealth in its relation to population. New York: Transaction Publishers.

-Schultz, Theodore. 1961. "Investment in human capital." The American Economic Review 51 (1): 1-17.

-Sraffa, Piero. 1929. Papers of Piero Sraffa (1898-1983), Economist. Copyright in Sraffa's own papers held by Professor Pierangelo Garegnani, Dipartimento di Economia, Terza Università degli Studi di Roma, Italy. Cambridge: Trinity College Library.

-Stedman-Jones, Gareth. 2006. "Saint-Simon and the liberal origins of the socialist critique of Political Economy." In Sylvie Aprile, Fabrice Bensimon, ed., La France et l'Angleterre au 19 e siècle. Echanges, représentations, comparaison. Paris: Créaphis, pp. 21-47. 